\title{
Arachidonic acid is a Major Component in Gonadal Fatty acids of Tropical Coral Reef fish in the Philippines and Japan
}

Ashraf Suloma** and Hiroshi Y. Ogata*

Fisheries Division, Japan International Research Center for Agricultural Sciences, Ohwashi 1-1, Tsukuba 305-8686, Japan

\begin{abstract}
The aim of the present study was to investigate the characteristics of gonadal fatty acid composition in 19 species of wild coral reef fish (Serranidae, Lutjanidae, Lethridae, Siganidae and Labridae) from Philippine (11 species of female) and Japanese ( 8 species of female and 5 species of male) waters with special attention to arachidonic acid (ArA), docosahexaenoic acid (DHA) and eicosapentaenoic acid (EPA) levels and their ratios. ArA levels were always higher than EPA levels in polar lipids of all the species and in neutral lipids in 17 of the 19 species. In ovarian polar lipids of the 19 species, ArA level ranged from $6.0 \%$ to $19.4 \%$, while EPA level ranged from $0.9 \%$ to $6.2 \%$. Ovarian DHA level was also always higher than EPA in all the species analyzed. Consequently, ArA/EPA ratios of these species were high, unlike cold- and temperate-water species. ArA was the top fatty acid component in testis polar lipids of three Lethrinus species (21.4\% to $22.9 \%)$. Thus, ArA is not a minor component, that is, the major highly unsaturated fatty acids (HUFAs) of polar lipids in all coral reef fish gonads are DHA and ArA (not EPA). The present information on gonadal fatty acid composition can be used as a guideline for advancing appropriate broodstock diets of tropical coral reef fish, emerging aquaculture commodities in developing countries.
\end{abstract}

Keywords: Arachidonic acid; EPA; DHA; Coral reef; Gonads; Fatty acids; Broodstock diets

\section{Introduction}

Coral reef fishes are commercially very important. Some species such as groupers and snappers are high-valued food fish and are emerging as aquaculture commodities in tropical and subtropical countries due to increasing demand [1]. Fry availability is an essential component in the development of the culture systems for new species and in further increasing production of established culture species [2]. However, the expansion of aquaculture of coral reef fish is hindered by unstable and limited supply of fry for aquaculture. At present, supply of the fry is mostly dependent on natural resources, and the reduction of the natural stock is a concern [3]. In responding to this situation, there has been considerable interest in developing reliable methods for spawning and rearing larvae and fry. Spawning and egg/larval quality are greatly affected by the quantity and quality of feed, and nutritional deficiency could be one of the reasons for inconsistent quality of spawns and fry. However, formulated broodstock diets for coral reef fish are still under development because of the lack of information on nutritional traits of these species.

Marine fish have low or no capacity to synthesize highly unsaturated fatty acids (HUFAs) from C18 fatty acids. HUFAs are important components of cell membranes and are thought to play important roles in membrane fluidity, modulation of enzyme activity, neural development and regulation of stress resistance. Especially, eicosapentaenoic acid (EPA: 20:5n-3) and docosahexaenoic acid (DHA: 22:6n-3) are considered as dietary essential fatty acids for normal growth and survival in most marine fish. Most of the studies have focused on the effects of dietary supplementation of EPA and DHA on broodstock performance. Indeed, dietary EPA and DHA have successfully improved reproductive performance and egg/larvae quality such as fecundity, embryo development, hatchability and survival in several species $[4,5]$. Thus, the importance of EPA and DHA in broodstock nutrition has been emphasized [6]. Little attention was given to the importance of dietary $n-6$ HUFA, especially arachidonic acid (ArA: 20:4n-6) in marine fish, because ArA is found in only small quantities in cold and temperate water fish, and dietary ArA was presumed to be unimportant in these species. Since Castell et al. [7] found the dietary essentiality of ArA in juvenile turbot (Scophthalmus maximus), the importance of ArA in fry production technologies of marine fish has been re-considered [8].

There have been some papers reporting that Australian or tropical marine fish contain ArA levels equivalent to or higher than those of EPA in muscle or edible parts [9-12] unlike cold and temperate water fish in the Northern Hemisphere. However, this fact has been overlooked in fry production of tropical or coral reef fish species. On the other hand, Ogata et al. found that ArA is not a minor component in the ovaries of several tropical species such as mangrove red snapper (Lutjanus argentimaculatus), rabbitfish (Siganus guttatus and S. canaliculatus), striped jack (Caranx fulvoguttatus) and coral trout (Plectropomus leopardus), suggesting that this fatty acid may be nutritionally much more important for egg development and larvae growth in the tropical species than in cold and temperate water species [13]. The degree of the preferential retention of ArA in gonadal polar lipids appears larger in tropical species than in cold and temperate water species. The degree of the physiological importance of ArA in reproduction and larvae/fry performance of tropical or coral reef fish might result in this difference in HUFA profile between tropical and cold/temperate species. When we consider the importance of dietary HUFA including ArA in fry production, as described above, we should pay more attention to HUFA characteristics in tropical fish.

The aim of the present study was to investigate the characteristic of

*Corresponding author: Hiroshi Y. Ogata National Research Institute of Aquaculture, FRA, Tamaki, Mie 519-0423, Japan, Tel. +81-596-58-6411; Fax. +81596-58-6413; E-mail: ogata1@affrc.go.jp

Received February 14, 2011; Accepted May 04, 2011; Published May 092011

Citation: Suloma A, Ogata HY (2011) Arachidonic acid is a Major Component in Gonadal Fatty acids of Tropical Coral Reef fish in the Philippines and Japan. J Aquac Res Development 2:111. doi:10.4172/2155-9546.1000111

Copyright: $\odot 2011$ Suloma A, et al. This is an open-access article distributed unde the terms of the Creative Commons Attribution License, which permits unrestricted use, distribution, and reproduction in any medium, provided the original author and source are credited. 
Citation: Suloma A, Ogata HY (2011) Arachidonic acid is a Major Component in Gonadal Fatty acids of Tropical Coral Reef fish in the Philippines and Japan. J Aquac Res Development 2:111. doi:10.4172/2155-9546.1000111

fatty acid composition of gonads in wild coral reef fish from Philippine (11 species of female) and Japanese (8 species of female and 5 species of male) waters, and special attention was paid to ArA, DHA and EPA levels and their ratios. Gonadal fatty acid composition in fish is affected by various biotic and abiotic factors, diets, species, size, age, maturity, temperature, seasons, salinity etc. Nevertheless, HUFA profile of gonads would be useful to develop broodstock diets for coral reef species where their requirement data are not yet available. Although the present information on gonadal fatty acid composition can be used as a guideline for developing appropriate broodstocks diets for coral reef fish, it should be noted that the conclusion of the present study is based solely on limited data. Absolute comparison of HUFA profile in coral reefs fish gonads would require much larger sample sizes and more systematic sampling from different locations, seasons, species, habitats and maturity.

\section{Materials and Methods}

\section{Fish species}

Nineteen species of wild coral reef fish were obtained from local dealers of three sites: Ishigaki (Okinawa, Japan), Puerto Princesa (Palawan, Philippines) and Igang (Guimaras, Philippines). Fish were immediately killed with iced water, transferred to local laboratories with ice and directly dissected to take gonad samples. The sampled gonads in Ishigaki were directly stored at $-80^{\circ} \mathrm{C}$ for a night and sent to our laboratory (Japan International Research Center for Agricultural Sciences, Tsukuba, Japan) with dry ice by air, and thus fatty acid composition in wet tissue was determined. Samples collected in Philippines were temporarily stored at $-20^{\circ} \mathrm{C}$, being freeze-dried, pulverized and sent by air. Fatty acid composition in dried tissue was determined for the samples collected in Philippines. Species name, body weight $(\mathrm{g})$, body length $(\mathrm{cm})$ and gonadosomatic index (GSI) were listed in Table 1. Of the samples, species names were not able to be identified in two species of Epinephelus that were collected at Puerto Princesa. The present paper gives them temporarily the names of Epinephelus sp. 1 and Epinephelus sp. 2 (Table 1).

\section{Analysis}

All the wet and dried samples were stored at $-80^{\circ} \mathrm{C}$ until lipid extraction. Lipid extraction was carried out with a mixture of chloroform and methanol $(2: 1, \mathrm{v} / \mathrm{v})$ [14] containing $0.01 \%$ butylhydroxytoluene (BHT). Total lipids were separated into polar (PL) and neutral lipids (NL) with a silica cartridge (Sep-pak plus, Waters, Milford, MA, USA) as described by [15] (Table 2). Fatty acid methyl esters (FAME) were prepared by transesterification with borontrifluoride in methanol according to the procedure of [16] and were purified with thin-layer chromatography (Silicagel 70 Plate, Wako, Osaka, Japan; solvent system: petroleum ether/diethyl ether/ acetic acid $=90: 10: 1, \mathrm{v} / \mathrm{v})$. FAME were analyzed using gas liquid chromatography (GC-17A; Shimadzu, Kyoto, Japan) equipped with a hydrogen flame ionization detector (FID) and an Omegawax 320 fused silica capillary column (30 m x $0.32 \mathrm{~mm}$ i.d.; Supelco, Bellefonte, PA, USA). The column temperature was initially held at $160 \mathrm{C}$ for $5 \mathrm{~min}$, followed by an increase at a rate of $4 \mathrm{C} / \mathrm{min}$ to a final temperature of $210^{\circ} \mathrm{C}$. The carrier gas was helium and the pressure was $80 \mathrm{kPa}$. Individual FAME was identified using a reference standard (Funakoshi, Tokyo, Japan) and known fish meal FAME and was quantified with an integrator (C-R7A plus; Shimadzu).

\section{Results}

Table 2 shows composition of total lipid (\%, wet basis for Ishigaki samples and dry basis for Philippine samples), neutral lipid (NL, \% of total lipid) and polar lipid (PL, \% of total lipid). The data of Lethrinus ornatus were not recorded due to a laboratory mistake. Total lipid levels

\begin{tabular}{|c|c|c|c|c|c|c|c|}
\hline \multirow{2}{*}{$\begin{array}{l}\text { Name } \\
\text { Family name }\end{array}$} & \multirow[b]{2}{*}{ Scientific name } & \multirow[b]{2}{*}{ English name } & \multicolumn{2}{|l|}{ Body } & \multirow{2}{*}{$\begin{array}{l}\text { Body } \\
\text { length }(\mathrm{cm}) \\
\end{array}$} & \multirow[b]{2}{*}{ GSI* } & \multirow[t]{2}{*}{$\begin{array}{l}\text { No. of } \\
\text { sample }\end{array}$} \\
\hline & & & Gonad & weight (g) & & & \\
\hline \multicolumn{8}{|l|}{ Ishigaki, Japan } \\
\hline Serranidae & Plectropomus leopardus & leopard coral grouper & ovary & $2265 \pm 215$ & $56.3 \pm 1.3$ & $0.2 \pm 0.1$ & 2 \\
\hline \multirow[t]{2}{*}{ Lutjanidae } & $\begin{array}{l}\text { Pristipomoides argyrogram- } \\
\text { micus }\end{array}$ & ornate jobfish & ovary & $535 \pm 35$ & $34.2 \pm 0.9$ & $0.4 \pm 0.1$ & 2 \\
\hline & Lutjanus gibbus & humpback snapper & ovary & $523 \pm 73$ & $32.0 \pm 1.5$ & $0.3 \pm 0$ & 2 \\
\hline \multirow[t]{5}{*}{ Lethridae } & Lethrinus miniatus & sweetlip emperor & ovary & $305 \pm 5$ & $25.3 \pm 0.3$ & $1.4 \pm 0.1$ & 2 \\
\hline & Lethrinus atkinsoni & $\begin{array}{l}\text { Pacific yellowtail } \\
\text { empero }\end{array}$ & testis & $458 \pm 3$ & $27.0 \pm 0.4$ & $2.6 \pm 0.1$ & 2 \\
\hline & & & ovary & $472 \pm 31$ & $27.8 \pm 0.4$ & $3.0 \pm 0.5$ & 2 \\
\hline & Lethrinus neblosus & spangled emperor & testis & $418 \pm 3$ & $28.0 \pm 0$ & $0.1 \pm 0$ & 3 \\
\hline & Lethrinus ornatus & ornate emperor & testis & $228 \pm 3$ & $20.0 \pm 0.1$ & $0.1 \pm 0$ & 3 \\
\hline \multirow[t]{5}{*}{ Siganidae } & Siganus guttatus & $\begin{array}{l}\text { orange-spotted rab- } \\
\text { bitfish }\end{array}$ & testis & $525 \pm 15$ & $28.2 \pm 0.2$ & $5.1 \pm 0.1$ & 3 \\
\hline & & & ovary & $605 \pm 156$ & $29.8 \pm 1.9$ & $7.1 \pm 1.9$ & 4 \\
\hline & Siganus canaliculatus & white-spotted rabbitfish & ovary & $537 \pm 61$ & $30.8 \pm 0.9$ & $15.4 \pm 2.0$ & 3 \\
\hline & Siganus virgatus & virgate rabbitfish & testis & $128 \pm 12.2$ & $17.4 \pm 0.3$ & $2.3 \pm 0.3$ & 3 \\
\hline & & & ovary & $143 \pm 13$ & $18.2 \pm 0.2$ & $1.8 \pm 0.0$ & 2 \\
\hline \multicolumn{8}{|c|}{ Puerto Princesa, Philippines } \\
\hline \multirow[t]{7}{*}{ Serranidae } & Cephalopholis argus & peacock grouper & ovary & $575 \pm 150$ & & $2.7 \pm 0.3$ & 2 \\
\hline & Cephalopholis cyanostigma & blue-spottedgrouper & ovary & $358 \pm 65$ & & $3.8 \pm 0.6$ & 3 \\
\hline & Epinephelus areolatus & areolate grouper & ovary & $350 \pm 53$ & & $1.8 \pm 0.4$ & 3 \\
\hline & Epinephelus quoyanus & longfin grouper & ovary & $500 \pm 100$ & & $0.3 \pm 0$ & 2 \\
\hline & Epinephelus sp. 1 & & ovary & $513 \pm 163$ & & $1.8 \pm 1.4$ & 2 \\
\hline & Epinephelus sp. 2 & & ovary & 550 & & 0.3 & 1 \\
\hline & Plectropomus leopardus & leopard coral grouper & ovary & $205 \pm 25$ & $25.0 \pm 0.6$ & $1.7 \pm 0.4$ & 3 \\
\hline \multirow[t]{2}{*}{ Lutjanidae } & Lutjanus decussatus & checkered snapper & ovary & & & & 2 \\
\hline & Lutjanus erythropterus & crimson snapper & ovary & $308 \pm 25$ & $28.0 \pm 0.6$ & $3.2 \pm 0.4$ & 3 \\
\hline Labridae & Cheilio inermis & cigar wrasse & ovary & $150 \pm 25$ & & $5.2 \pm 1.7$ & 3 \\
\hline \multicolumn{8}{|l|}{ Igang, Philippines } \\
\hline Siganidae & Siganus canaliculatus & white-spotted rabbitfish & ovary & $225 \pm 25$ & $28.5 \pm 1.5$ & $8.6 \pm 0.5$ & 2 \\
\hline
\end{tabular}

${ }^{*}$ Gonadosomatic index: (weight of gonad)/(body weight)

Table 1: Fish name, body weight, body length and gonadosomatic index of sample fish (average \pm S.E.) and number of sample. 
Citation: Suloma A, Ogata HY (2011) Arachidonic acid is a Major Component in Gonadal Fatty acids of Tropical Coral Reef fish in the Philippines and Japan. J Aquac Res Development 2:111. doi:10.4172/2155-9546.1000111

Page 3 of 7

\begin{tabular}{|c|c|c|c|c|}
\hline Source & Fish name & TL $(\%)$ & $\mathrm{PL}(\%)$ & $\mathrm{NL}(\%)$ \\
\hline \multirow{8}{*}{ Japan ovary } & Plectropomus leopardus & $2.0 \pm 0.3$ & $38.7 \pm 5.6$ & $61.3 \pm 5.6$ \\
\hline & Pristipomoides argyrogrammicus & $2.6 \pm 0.1$ & $61.4 \pm 1.4$ & $38.6 \pm 1.4$ \\
\hline & Lutjanus gibbus & $4.6 \pm 0.3$ & $58.9 \pm 4.1$ & $41.1 \pm 4.1$ \\
\hline & Lethrinus miniatus & $5.0 \pm 0.3$ & $33.5 \pm 2.1$ & $66.5 \pm 2.1$ \\
\hline & Lethrinus atkinsoni & $4.9 \pm 0.6$ & $63.9 \pm 1.2$ & $36.1 \pm 1.2$ \\
\hline & Siganus guttatus & $8.4 \pm 0.9$ & $28.5 \pm 0.8$ & $71.5 \pm 0.8$ \\
\hline & Siganus canaliculatus & $11.0 \pm 0.6$ & $31.4 \pm 0.4$ & $68.6 \pm 0.4$ \\
\hline & Siganus virgatus & $3.6 \pm 0.1$ & $12.3 \pm 1.2$ & $87.7 \pm 1.2$ \\
\hline \multirow[t]{11}{*}{ Philippines ovary } & Cephalopholis argus & $17.2 \pm 2.5$ & $53.3 \pm 19.4$ & $46.7 \pm 19.4$ \\
\hline & Cephalopholis cyanostigma & $20.4 \pm 1.4$ & $34.5 \pm 0.7$ & $65.5 \pm 0.7$ \\
\hline & Epinephelus areolatus & $20.6 \pm 1.0$ & $44.2 \pm 1.9$ & $55.8 \pm 1.9$ \\
\hline & Epinephelus quoyanus & $12.4 \pm 0.6$ & $83.6 \pm 2.1$ & $16.4 \pm 2.1$ \\
\hline & Epinephelus sp.1 & $18.4 \pm 1.4$ & $86.7 \pm 0.4$ & $13.3 \pm 0.4$ \\
\hline & Epinephelus sp.2 & 4.2 & 41.4 & 58.6 \\
\hline & Plectropomus leopardus & $17.8 \pm 3.3$ & $37.2 \pm 0.2$ & $62.8 \pm 0.2$ \\
\hline & Lutjanus decussatus & $28.0 \pm 16.2$ & $28.2 \pm 15.4$ & $71.8 \pm 15.4$ \\
\hline & Lutjanus erythropterus & $23.5 \pm 0.9$ & $36.3 \pm 1.8$ & $63.8 \pm 1.8$ \\
\hline & Cheilio inermis & $22.7 \pm 1.2$ & $35.1 \pm 1.4$ & $64.9 \pm 1.4$ \\
\hline & Siganus canaliculatus & $24.6 \pm 2.5$ & $31.5 \pm 4.4$ & $68.5 \pm 4.4$ \\
\hline Average & & & $44.8 \pm 4.6$ & $55.2 \pm 4.6$ \\
\hline \multicolumn{5}{|l|}{ Japan testis } \\
\hline & Lethrinus atkinsoni & $2.4 \pm 0.0$ & $74.8 \pm 2.3$ & $25.2 \pm 2.3$ \\
\hline & Lethrinus nebulosus & $1.2 \pm 0.1$ & $57.5 \pm 0.8$ & $42.6 \pm 0.8$ \\
\hline & Lethrinus ornatus & nd & nd & nd \\
\hline & Siganus guttatus & $2.6 \pm 0.3$ & $43.7 \pm 3.3$ & $56.3 \pm 3.3$ \\
\hline & Siganus virgatus & $3.4 \pm 0.5$ & $53.5 \pm 6.1$ & $46.5 \pm 6.1$ \\
\hline Average & & & $57.4 \pm 6.5$ & $42.7 \pm 6.5$ \\
\hline
\end{tabular}

* Wet basis for Ishigaki samples and dry basis for Philippine samples.

Table 2: Composition of total lipid $(\%)^{*}$, neutral lipid (NL, \% of total lipid) and polar lipid (PL, \% of total lipid) (mean value $\left.\pm S . E.\right)$.

ranged from $2.0 \%$ to $11.0 \%$ in ovaries (wet basis, Ishigaki), from $4.2 \%$ to $28.0 \%$ in ovaries (dry basis, Philippines) and from $1.2 \%$ to $3.4 \%$ in testes (wet basis, Ishigaki), respectively. The ranges of polar lipid levels in ovaries and testes were respectively from $12.3 \%$ to $86.7 \%$ and from $43.7 \%$ to $74.8 \%$, those of neutral lipid levels in ovaries and testes being respectively from $13.3 \%$ to $87.7 \%$ and from $25.2 \%$ to $56.3 \%$.

Major fatty acids (\% of total fatty acids) of the gonads in wild coral reef fish are shown in Tables 3 for polar lipids and 4 for neutral lipids. The most striking result in the present study was that ArA levels were always higher than EPA levels in polar lipids of all the gonad samples analyzed, and that in 17 of the 19 species, ArA levels were also higher than EPA levels in neutral lipids of their gonads. In ovarian polar lipids, ArA levels ranged from 6.0\% (Epinephelus areolatus) to $19.4 \%$ (Lethrinus atkinsoni), while EPA levels ranged from 0.9\% (Siganus virgatus) to $6.2 \%$ (Pristipomoide argyrogrammicus). The minimum and the maximum ArA/EPA ratios in ovarian polar lipids were 1.3 in E. areolatus and 15.6 in Plectropomus leopardus (Japan). ArA in ovarian polar lipids was one of the top three fatty acid components in Cephalopholis argus (12.6\% with an ArA/EPA ratio of 3.3), Epinephelus quoyanus (15.2\% with a ratio of 9.1), Epinephelus. sp.-1 (11.4\% with a ratio of 5.3), Epinephelus sp.-2 (11.7\% with a ratio of 3.4), Lutjanus decussatus (16.5\% with a ratio of 5.3), Lutjanus erythropterus $(17.5 \%$ with a ratio of 4.1), P. leopardus (Japan) (19.2\% with a ratio of 15.6), Lutjanus gibbus (12.3\% with a ratio of 4.3$)$, Lethrinus miniatus $(17.3 \%$ with a ratio of 3.6), Siganus canaliculatus (Japan) (9.9\% with a ratio of 4.7), L. atkinsoni (19.4\% with a ratio of 4.1$)$, Siganus guttatus $(12.7 \%$ with a ratio of 5.3 ) and $S$. virgatus (8.9\% with a ratio of 10.0). Irrespective of the maturity, thus, ovarian polar lipids had higher levels of ArA than EPA levels, for instance in P. leopardus (Japan) (immature, Tables 1 and 3) and S. canaliculatus (mature, Tables 1 and 3). DHA was also one of the top three fatty acid components in ovarian polar lipids in 15 of the 19 species. Ovarian DHA level in polar lipids was always higher than EPA in all the species analyzed, ranging from $7.9 \%$ with DHA/EPA ratio of 8.9 (S. virgatus) to $27.8 \%$ with a ratio of 18.3 (S. canaliculatus). DHA levels in ovarian polar lipids were lower in the six species and higher in the remaining species than ArA levels, respectively. The variation of DHA/ArA ratios with the range from 0.5 (P. leopardas, Japan) to 4.2 (E. areolatus) was relatively small among species, compared to those of ArA/EPA (1.3-15.6) and DHA/EPA (3.0-18.3) ratios. Surprisingly, ArA was the top fatty acid component in testis polar lipids of Lethrinus ornatus (22.9\%), Lethrinus nebulosus (22.5\%) and L. atokinsoni (21.4\%). Consequently, ArA/EPA ratios of these species were extremely high with the range from 8.4 to 20.2. ArA levels in testis polar lipids of two Siganus species were intermediate but higher than EPA levels with the ArA/EPA ratios of 10.0 and 6.1 .

ArA, EPA and DHA levels in neutral lipids (Table 4) were lower than those in polar lipids due to relatively high levels of 16:0, 18:0 and 18:1n9 fatty acids in neutral lipids in gonad tissues. Yet, in neutral lipids, ArA levels were entirely higher than EPA levels throughout all the species with the exception of E. areolatus ovary and P. leopardus (Philippines) ovary. ArA, EPA and DHA levels in neutral lipids of ovaries ranged from $1.3 \%$ (Cephalopholis cyanostigma and E. areolatus) to $10.1 \%$ (S. virgatus), from $0.5 \%$ (C. argus) to $4.9 \%$ (P. argyrogrammicus) and from $0.7 \%$ (C. argus) to $16.7 \%$ (P. argyrogrammicus), respectively. These HUFA levels in testes ranged from $4.6 \%$ (L. ornatus) to $14.3 \%$ ( $L$. atokinsoni), from $1.3 \%$ (L. atokinsoni) to $2.8 \%$ (L. ornatus) and from $1.6 \%$ (L. ornatus) to $10.4 \%$ (S. guttatus), respectively.

\section{Discussion}

It is obvious that ArA is not a minor HUFA but an essential component in gonads of wild coral reef fish, judging from the results of the present study and our previous paper that intermediate or high ArA and DHA levels with relatively low EPA level were found in ovaries, eggs, fry and/or muscle of mangrove red snapper (L. argentimaculatus), two species of rabbitfish (S. guttatus and S. canaliculatus), striped jack (C. fulvoguttatus) and coral trout (P. leopardus) sampled in Central Philippines [13]. Earlier papers reported that muscle tissue or edible part of Australian [9, 11], Malaysian [10] and Arabian Gulf [12] marine fish were rich in ArA whose level was equivalent to or higher than EPA level, unlike cold and temperate water species in the Northern 
Citation: Suloma A, Ogata HY (2011) Arachidonic acid is a Major Component in Gonadal Fatty acids of Tropical Coral Reef fish in the Philippines and Japan. J Aquac Res Development 2:111. doi:10.4172/2155-9546.1000111

\begin{tabular}{|c|c|c|c|c|c|c|c|c|c|c|c|c|c|c|c|}
\hline & $16: 0$ & 18:0 & $\begin{array}{l}18: 1 \\
n-9\end{array}$ & $\begin{array}{l}18: 2 \\
n-6\end{array}$ & $\begin{array}{l}18: 3 \\
n-3\end{array}$ & $\begin{array}{l}20: 4 \\
n-6\end{array}$ & $\begin{array}{l}20: 5 \\
n-3\end{array}$ & $\begin{array}{l}22: 6 \\
n-3\end{array}$ & ¿satu-rates & ¿mono-enes & $\begin{array}{l}\Sigma \\
n-6\end{array}$ & $\begin{array}{l}\Sigma \\
n-3\end{array}$ & $\begin{array}{l}\text { ArA } \\
\text { /EPA }\end{array}$ & $\begin{array}{l}\text { DHA } \\
\text { /EPA }\end{array}$ & $\begin{array}{l}\text { DHA } \\
\text { IArA }\end{array}$ \\
\hline \multicolumn{16}{|l|}{ Japan, ovary } \\
\hline Plectropomus leopardus & 19.0 & 12.6 & 7.3 & 0.9 & 0.1 & 19.2 & 1.2 & 9.3 & 34.5 & 14.8 & 29.3 & 13.3 & 15.6 & 7.6 & 0.5 \\
\hline $\begin{array}{l}\text { Pristipomoides argyrogram- } \\
\text { micus }\end{array}$ & 17.6 & 8.8 & 13.6 & 1.1 & 0.2 & 10.7 & 6.2 & 18.4 & 27.9 & 19.1 & 19.3 & 28.4 & 1.7 & 3.0 & 1.7 \\
\hline Lutjanus gibbus & 22.4 & 9.8 & 9.5 & 1.6 & 0.2 & 12.3 & 2.9 & 16.1 & 34.1 & 13.4 & 24.6 & 23.5 & 4.3 & 5.7 & 1.3 \\
\hline Lethrinus miniatus & 21.4 & 10.7 & 6.7 & 1.4 & 0.2 & 17.3 & 4.8 & 14.8 & 35.0 & 11.2 & 24.6 & 24.5 & 3.6 & 3.1 & 0.9 \\
\hline Lethrinus atkinsoni & 19.7 & 11.1 & 8.0 & 1.5 & 0.3 & 19.4 & 4.8 & 14.4 & 33.3 & 11.2 & 26.8 & 25.2 & 4.1 & 3.1 & 0.7 \\
\hline Siganus guttatus & 27.0 & 7.3 & 7.4 & 0.9 & 0.2 & 12.7 & 2.7 & 19.9 & 37.0 & 11.1 & 19.5 & 28.4 & 5.3 & 10.3 & 1.6 \\
\hline Siganus canaliculatus & 31.1 & 5.6 & 5.8 & 0.7 & 0.2 & 9.9 & 2.3 & 27.0 & 39.3 & 8.4 & 14.8 & 35.1 & 4.7 & 13.1 & 2.7 \\
\hline Siganus virgatus & 23.4 & 11.4 & 6.4 & 0.7 & $\operatorname{tr}$ & 8.9 & 0.9 & 7.9 & 45.4 & 10.5 & 15.6 & 13.5 & 10.0 & 8.9 & 0.9 \\
\hline \multicolumn{16}{|l|}{ Philippines, ovary } \\
\hline Cephalopholis argus & 23.9 & 11.3 & 11.0 & 1.0 & 0.1 & 12.6 & 3.8 & 12.3 & 37.8 & 16.4 & 19.0 & 20.4 & 3.3 & 3.2 & 1.0 \\
\hline Cephalopholis cyanostigma & 20.0 & 12.4 & 8.4 & 0.7 & 0.1 & 7.8 & 5.2 & 25.1 & 34.6 & 13.3 & 14.5 & 33.6 & 1.5 & 4.8 & 3.2 \\
\hline Epinephelus areolatus & 22.0 & 11.7 & 8.1 & 0.7 & $\operatorname{tr}$ & 6.0 & 4.7 & 24.6 & 36.4 & 13.8 & 11.4 & 32.2 & 1.3 & 5.3 & 4.2 \\
\hline Epinephelus quoyanus & 18.1 & 12.3 & 14.0 & 1.0 & 0.2 & 15.2 & 1.7 & 8.8 & 33.1 & 22.1 & 23.9 & 13.5 & 9.1 & 5.3 & 0.6 \\
\hline Epinephelus sp.1 & 23.4 & 11.2 & 11.2 & 0.9 & 0.3 & 11.4 & 2.2 & 9.6 & 36.5 & 16.5 & 20.6 & 14.5 & 5.3 & 4.4 & 0.8 \\
\hline Epinephelus sp.2 & 22.5 & 11.2 & 10.0 & 0.7 & 0.2 & 11.7 & 3.4 & 16.3 & 36.3 & 15.0 & 20.4 & 23.3 & 3.4 & 4.8 & 1.4 \\
\hline Plectropomus leopardus & 25.6 & 10.2 & 7.6 & 0.8 & $\operatorname{tr}$ & 7.8 & 5.1 & 20.9 & 38.7 & 14.0 & 13.1 & 27.8 & 1.6 & 4.1 & 2.8 \\
\hline Lutjanus decussatus & 8.6 & 12.5 & 7.1 & 0.6 & 0.3 & 16.5 & 3.3 & 23.4 & 22.8 & 11.8 & 27.5 & 30.7 & 5.3 & 7.3 & 1.4 \\
\hline Lutjanus erythropterus & 14.4 & 15.7 & 8.2 & 1.0 & 0.1 & 17.5 & 4.3 & 18.3 & 31.4 & 11.8 & 25.3 & 26.9 & 4.1 & 4.2 & 1.0 \\
\hline Cheilio inermis & 27.9 & 9.3 & 10.8 & 0.9 & 0.3 & 9.4 & 3.5 & 12.2 & 41.1 & 17.3 & 16.7 & 20.1 & 2.7 & 3.6 & 1.3 \\
\hline Siganus canaliculatus & 30.6 & 6.7 & 7.7 & 2.5 & 0.2 & 6.8 & 1.5 & 27.8 & 40.0 & 10.8 & 13.5 & 32.4 & 4.5 & 18.3 & 4.1 \\
\hline \multicolumn{16}{|l|}{ Japan, testis } \\
\hline Lethrinus atkinsoni & 19.1 & 9.2 & 12.0 & 1.4 & 0.4 & 21.4 & 1.1 & 14.4 & 31.3 & 16.1 & 30.3 & 18.1 & 20.2 & 13.6 & 0.7 \\
\hline Lethrinus nebulosus & 17.5 & 13.2 & 6.8 & 1.6 & $\operatorname{tr}$ & 22.5 & 2.2 & 4.9 & 35.5 & 13.0 & 30.9 & 10.8 & 10.2 & 2.2 & 0.2 \\
\hline Lethrinus ornatus & 21.2 & 12.1 & 9.3 & 1.5 & tr & 22.9 & 2.7 & 4.5 & 36.8 & 14.7 & 30.2 & 10.2 & 8.4 & 1.6 & 0.2 \\
\hline Siganus guttatus & 27.0 & 11.8 & 8.3 & 3.2 & 1.5 & 6.7 & 1.7 & 11.9 & 41.7 & 11.8 & 15.6 & 20.7 & 3.9 & 6.8 & 1.8 \\
\hline Siganus virgatus & 28.1 & 12.6 & 9.0 & 1.0 & 0.3 & 7.9 & 1.3 & 9.6 & 47.0 & 12.8 & 15.0 & 15.8 & 6.1 & 8.2 & 1.2 \\
\hline
\end{tabular}

Table 3: Major fatty acids (\% of total fatty acids) in polar lipids of gonads of 19 species of coral reef fish from Philippines and Japanese water.

\begin{tabular}{|c|c|c|c|c|c|c|c|c|c|c|c|c|c|c|c|}
\hline & $16: 0$ & 18:0 & $\begin{array}{l}18: 1 \\
n-9\end{array}$ & $\begin{array}{l}18: 2 \\
n-6\end{array}$ & $\begin{array}{l}18: 3 \\
n-3\end{array}$ & $\begin{array}{l}20: 4 \\
n-6\end{array}$ & $\begin{array}{l}20: 5 \\
n-3\end{array}$ & $\begin{array}{l}22: 6 \\
n-3\end{array}$ & ¿satu-rates & Emono-enes & $\begin{array}{l}\Sigma \\
n-6\end{array}$ & $\begin{array}{l}\Sigma \\
n-3\end{array}$ & $\begin{array}{l}\text { ArA } \\
\text { /EPA }\end{array}$ & $\begin{array}{l}\text { DHA } \\
\text { /EPA }\end{array}$ & $\begin{array}{l}\text { DHA } \\
\text { IArA }\end{array}$ \\
\hline \multicolumn{16}{|l|}{ Japan, ovary } \\
\hline Plectropomus leopardus & 31.4 & 8.2 & 9.4 & 1.6 & 0.5 & 7.0 & 2.1 & 5.1 & 46.1 & 21.3 & 15.0 & 11.4 & 3.4 & 2.5 & 0.7 \\
\hline Pristipomoides argyrogrammicus & 16.2 & 11.2 & 12.4 & 1.2 & 0.3 & 9.1 & 4.9 & 16.7 & 29.5 & 19.6 & 16.8 & 25.4 & 1.8 & 3.4 & 1.8 \\
\hline Lutjanus gibbus & 24.3 & 10.5 & 9.7 & 1.3 & 0.4 & 4.3 & 1.5 & 3.7 & 45.2 & 26.1 & 10.7 & 8.2 & 3.0 & 2.5 & 0.8 \\
\hline Lethrinus miniatus & 27.3 & 8.9 & 15.7 & 1.6 & 0.7 & 3.7 & 1.7 & 2.6 & 44.2 & 36.1 & 8.2 & 6.6 & 2.2 & 1.5 & 0.7 \\
\hline Lethrinus atkinsoni & 30.9 & 9.3 & 13.4 & 3.2 & 1.3 & 7.4 & 3.1 & 3.3 & 47.0 & 24.5 & 14.6 & 10.8 & 2.4 & 1.1 & 0.4 \\
\hline Siganus guttatus & 29.0 & 3.1 & 12.6 & 2.2 & 1.3 & 4.3 & 2.6 & 7.0 & 38.9 & 30.5 & 9.6 & 16.4 & 1.9 & 3.2 & 1.6 \\
\hline Siganus canaliculatus & 32.2 & 4.3 & 15.4 & 2.5 & 1.3 & 3.9 & 1.6 & 6.9 & 41.3 & 27.8 & 10.5 & 16.2 & 3.2 & 5.5 & 1.8 \\
\hline Siganus virgatus & 29.1 & 7.9 & 16.6 & 1.3 & 0.5 & 10.1 & 1.7 & 6.0 & 41.3 & 24.6 & 16.3 & 14.9 & 5.8 & 3.4 & 0.6 \\
\hline \multicolumn{16}{|l|}{ Philippines, ovary } \\
\hline Cephalopholis argus & 41.1 & 16.7 & 10.3 & 1.1 & 0.1 & 1.8 & 0.5 & 0.7 & 63.6 & 22.5 & 5.8 & 2.3 & 3.7 & 1.5 & 0.4 \\
\hline Cephalopholis cyanostigma & 38.7 & 8.7 & 16.2 & 0.8 & 0.2 & 1.3 & 1.0 & 4.9 & 54.0 & 29.8 & 4.5 & 7.4 & 1.5 & 4.3 & 4.1 \\
\hline Epinephelus areolatus & 31.0 & 7.7 & 14.8 & 1.0 & 0.3 & 1.3 & 2.0 & 11.4 & 45.3 & 29.5 & 4.2 & 15.9 & 0.6 & 5.7 & 8.8 \\
\hline Epinephelus quoyanus & 29.3 & 11.5 & 18.2 & 0.6 & 0.7 & 2.6 & 1.0 & 7.3 & 45.6 & 27.0 & 10.4 & 10.5 & 3.3 & 8.1 & 3.8 \\
\hline Epinephelus sp.1 & 32.1 & 11.5 & 16.2 & 0.5 & 0.6 & 1.8 & 1.1 & 6.0 & 47.6 & 27.0 & 7.8 & 2.7 & 1.8 & 5.3 & 7.1 \\
\hline Epinephelus sp.2 & 36.1 & 6.6 & 17.0 & 0.9 & 0.4 & 2.4 & 0.9 & 2.4 & 48.2 & 34.1 & 6.0 & 4.5 & 2.8 & 2.8 & 1.0 \\
\hline Plectropomus leopardus & 28.5 & 8.4 & 16.8 & 0.9 & 0.2 & 2.2 & 2.4 & 12.0 & 43.2 & 28.6 & 5.3 & 15.7 & 0.9 & 5.0 & 5.7 \\
\hline Lutjanus decussatus & 31.9 & 14.3 & 10.3 & 0.8 & 0.7 & 1.7 & 1.5 & 4.0 & 55.4 & 22.6 & 5.1 & 8.0 & 1.0 & 2.2 & 2.2 \\
\hline Lutjanus erythropterus & 26.4 & 12.8 & 12.2 & 1.9 & 0.2 & 4.8 & 2.0 & 3.2 & 46.7 & 26.1 & 12.3 & 7.2 & 2.4 & 1.6 & 0.7 \\
\hline Cheilio inermis & 38.9 & 10.3 & 11.3 & 1.1 & 0.4 & 1.9 & 1.0 & 1.8 & 60.1 & 25.1 & 6.2 & 5.0 & 2.2 & 2.0 & 0.9 \\
\hline Siganus canaliculatus & 27.8 & 6.6 & 23.7 & 5.1 & 0.6 & 1.7 & 0.7 & 6.8 & 38.5 & 37.0 & 9.8 & 10.6 & 2.4 & 9.2 & 3.9 \\
\hline \multicolumn{16}{|l|}{ Japan, testi } \\
\hline Lethrinus atkinsoni & 26.2 & 11.9 & 8.2 & 1.7 & $\operatorname{tr}$ & 14.3 & 1.3 & 7.6 & 43.8 & 15.7 & 24.0 & 11.3 & 10.8 & 5.7 & 0.5 \\
\hline Lethrinus nebulosus & 24.8 & 15.3 & 12.0 & 2.0 & 0.6 & 10.9 & 2.4 & 3.8 & 45.9 & 22.0 & 17.5 & 9.1 & 4.5 & 1.6 & 0.4 \\
\hline Lethrinus ornatus & 30.2 & 11.3 & 20.9 & 2.1 & 0.8 & 4.6 & 2.8 & 1.6 & 47.6 & 31.7 & 9.8 & 7.3 & 1.6 & 0.6 & 0.3 \\
\hline Siganus guttatus & 26.2 & 8.8 & 10.4 & 5.5 & 2.9 & 10.0 & 2.5 & 10.4 & 37.0 & 19.0 & 21.0 & 22.2 & 3.9 & 4.1 & 1.0 \\
\hline Siganus virgatus & 26.0 & 10.1 & 12.5 & 1.7 & 0.5 & 13.2 & 2.1 & 9.7 & 39.0 & 18.1 & 22.4 & 18.5 & 6.7 & 5.2 & 0.7 \\
\hline
\end{tabular}

Table 4: Major fatty acids (\% of total fatty acids) in neutral lipids of gonads of 19 species of coral reef fish from Philippines and Japanese water.

Hemisphere. Mitochondrial membranes (liver and heart) of three coral reef species had a significantly higher proportion of ArA than those of cold water species, excluding Mugil cephalus (coastal and estuarine species) [17]. On the other hand, few papers have been available on gonadal fatty acid composition of wild coral reef fish, especially in commercially important species which are emerging as new aquaculture commodities. Alava et al. [18] reported a relatively high ArA level in wild-sourced grouper (Epinephelus coioides) broodstock (GSI: 0.73) that the levels of HUFA were: DHA (13.1\%) > ArA (5.1\%) > EPA (1.9\%) with a DHA/EPA ratio of 6.8 and a DHA/ArA ratio of 2.5 in the ovarian total lipids. Fatty acid compositions of ovaries, eggs and fry from not wild but reared broodstock at tropical and subtropical hatcheries have been reported in striped mullet (Mugil cephalus) (coastal, estuarine and bethopelagic species) [19], milkfish (Chanos chanos) (coastal, estuarine and bethopelagic species) [20], Asian seabass (Lates calcarifer) (coastal, estuarine and demersal species) [21], white sea bream (Diplodus sargus) (demersal and oceanodromous species) [22] and cobia (Rachycentron canadum) (reef-associated pelagic species) [23]. Since gonadal fatty acid profile is greatly affected by feeds that have been fed during rearing period, the results of the hatchery-raised broodstock are not directly compared with the present ones based on wild coral reef fish. In general, gonads and eggs of high and temperate latitude species in the northern hemisphere have high levels of EPA and DHA, and consequently most of these species show extremely low ArA/EPA ratios [24, 25]. The average 
levels of ArA, EPA and DHA in egg polar lipids of seven Northwest European species (wild) were $1.9 \%, 14.6 \%$ and $28.0 \%$, respectively [24]. The average levels of ArA, EPA and DHA in ovarian polar lipids of eight cold and temperate water species (wild) sampled in the Pacific Ocean were $4.1 \%, 13.1 \%$ and $22.0 \%$, respectively [25]. In these species, EPA levels were always higher than ArA levels with the exception of Beryx splendens (bentopelagic species) in which ArA and EPA levels were $5.4 \%$ and $4.6 \%$, respectively (this specimen was sampled at $33^{\circ} \mathrm{N}$ and $139^{\circ} \mathrm{E}$ ). In the present result, however, ArA level was always higher than EPA level in ovaries of all the species examined, irrespective of the species, sampling location and a wide range of gonadosomatic index. The average levels of ArA, EPA and DHA in ovaries of the coral reef species were $12.3 \%, 3.4 \%$ and $17.2 \%$ in polar lipids and $3.9 \%, 1.8 \%$ and $5.9 \%$ in neutral lipids, respectively. In this connection, eggs of six Australian but freshwater or brackish water species (wild) have high or middle DHA (8.2-29.3\%) and ArA (1.8-15.3\%) levels with low EPA level $(0.2-2.2 \%)$ in their polar lipids [26] as did the coral reef species. We might say that coral reef fish appear to have a comparable ArA/EPA ratio with freshwater fish rather than cold and temperate water marine fish.

Not only the concentration but also the mutual ratio of DHA, EPA and ArA in diets may be important, and that the dietary optimum ratio appears to vary depending on species, stage, the geography and the species inhabits. In the present study, ovaries of 17 species of coral reef fish had average ratios of: ArA/EPA of 4.8, DHA/EPA of 6.2 and DHA/ ArA of 1.7 in polar lipids and ArA/EPA of 2.5, DHA/EPA of 3.8 and DHA/ArA of 2.5 in neutral lipids, respectively. This result indicates that ovarian DHA/ArA ratio is about 2 in tropical coral reef fish, suggesting that the DHA/ArA (not EPA) ratio of around or more than 2 may be optimum for broodstock diets, especially for ovary development in coral reef fish. We, therefore, recommend a dietary ratio of DHA/ ArA (not EPA) of about 2 or greater as an ideal for broodstock diets of tropical coral reef fish.

Information on testis fatty acid composition of wild fish has been relatively scarce compared to ovaries and eggs. However, there have been several papers reporting the effects of HUFA on male reproductive performance in cold and temperate water species $[27,28]$. The present study showed that ArA was the major HUFA in testis as well as in ovary of the coral reef fish, especially in their polar lipids. Particularly, testis ArA levels in polar lipids of the three Lethrinus species were more than $20 \%$. The average levels of ArA, EPA and DHA in testis polar lipids of nine species of cold and temperate water fish were $2.7 \%, 10.8 \%$ and $28.1 \%$, respectively [25]. The range of ArA, EPA and DHA levels in testis polar lipids of three cold water marine species (Clupea pallasi, Theragra chalcogramma and Osmerus eperlanus mordax) were from $1.2 \%$ to $4.6 \%$, from $9.9 \%$ to $17.0 \%$ and from $14.1 \%$ to $20.9 \%$, respectively [29]. In skipjack tuna Euthynnus pelamis (sampled in the Southern fishing ground in the Pacific Ocean), testis polar lipids had ArA of 3.6\%, EPA of $3.5 \%$ and DHA of $32.5 \%$, respectively[30]. It is also clear that the testes of the coral reef fish analyzed here have higher ArA levels and ArA/ EPA ratios than those of cold and temperate water species. This result suggests that ArA tends to be specifically much more concentrated in testis of wild coral reef fish, and that the degree of the essentiality of ArA during male reproductive process may be much greater in coral reef fish compared to cold and temperate water species.

Testes of the five species of coral reef fish had average ratios of: ArA/ EPA of 9.8, DHA/EPA of 6.5 and DHA/ArA of 0.8 in polar lipids and ArA/EPA of 5.5, DHA/EPA of 3.4 and DHA/ArA of 0.6 in neutral lipids, respectively. This result suggest that since the average DHA/ArA ratio was smaller in the testis than in the ovary, the optimum dietary ratio of HUFA during gonadogenesis might be different between males and females, and moreover that the degree of the physiological essentiality of ArA might be greater in testis than in ovary.

The high ArA levels in gonads observed in the present study shows that coral reef fish species may require much more ArA for normal gonadogenesis and embryo development than cold and temperate water species, although dietary ArA tends to be concentrated in gonads, eggs and sperm even in cold and temperate water species. ArA as an eicosanoid precursor is well known to be multifunctional in fish reproduction including pheromonal activity in mating behavior [31, 32]: induction of ovulation [33], stimulation of steroidgenesis in ovary [34] and testes [35], interaction of gonadotropin and prostaglandin production [36]. Coral reef fish have, in general, a longer spawning period (from March through December) compared to cold and temperate water species, and they spawn once a month during the spawning period according to lunar phase. This mode of reproduction might increase the degree of the essentiality of ArA in the reproduction of coral reef fish compared with cold and temperate water fish. On the other hand, tropical species hatch-out in a short time (usually less than $24 \mathrm{~h}$ ) during which the embryo has to build up many biological systems, while cold water species such as salmonids take a longer time, one or two months, to hatch out. Very fast embryo development in tropical species might increase the degree of the essentiality of ArA, prostaglandins and other eicosanoids. Heavy raining and typhoons bring critical changes of temperature, salinity, irregular currents and turbidity. The environmental stresses may further increase the degree of the necessity for the eicosanoids, although the effectiveness of dietary ArA appears different between the types of stress, acute (handling stress) and chronic (salinity change) [37].

It is widely accepted that fatty acid composition of fish tissues reflects dietary fatty acid composition. It is also obvious that ArA level in tissues including gonads is affected by dietary ArA level. When we consider the fact that most of marine fish lack the de novo ability to produce HUFA, the coral reef fish should also rely on a dietary supply of HUFA from the food web. EPA and DHA in fish have been known to be derived from the pelagic food chain from phytoplankton to accumulate in higher order carnivores, especially in pelagic species and deeper offshore demersal species [38]. All the species investigated in the present study were reef-associated species. Serranidae, Lujanidae, Lethridae and Labridae are carnivores, which feed on smaller fishes, crabs, shrimps, cephalopods, polychaeta worms, gastropods and urochordates. Sigaidae are herbivores, which feed mainly on benthic macroalgae. The coral reef fish perhaps depend heavily on their natural food as their ArA sources (without doubt), although there might be a special mechanism by which they store much more preferentially ArA in their gonads than cold and temperate water fish.

Renaud et al. [39] investigated fatty acid composition of 18 species of tropical Australian microalgae [39]. Only two pelagic species, Nitzschia sp. and Fragilarias sp. had relatively high ArA levels equivalent to EPA levels, but in the remaining 16 species, EPA was the major HUFA and ArA level was low. EPA was also the major HUFA in tropical phytoplankton sampled from coastal waters of the South China Sea during one year cycle [40]. In tropical paracalanid copepods, EPA level is higher than ArA level with DHA/EPA/ArA ratios of 14:3:1 for Acartia sinjiensis, 20:9:1 for Parvocalanus crassirostris and 25:6:1 for Bestiolina similes, respectively [41]. Thus, planktonic microorganisms do not appear to be the primary source of ArA even in tropical waters. High ArA levels are found in some species of marine red and brown seaweeds 
Citation: Suloma A, Ogata HY (2011) Arachidonic acid is a Major Component in Gonadal Fatty acids of Tropical Coral Reef fish in the Philippines and Japan. J Aquac Res Development 2:111. doi:10.4172/2155-9546.1000111

from both temperate and tropical waters, although this phenomenon is not always limited to tropical areas [42-44]. Nevertheless, red and brown seaweeds may be at least one of the sources. Dunstan et al.[45] found that in temperate marine fish from Southern Australian coastal waters, demersal omnivore species (macroalgae consumers) have relatively high ArA/EPA ratio (0.9) compared to demersal carnivores (0.6) and pelagic carnivores (0.2) [45]. Thus, ArA appears to be provided primarily from some organisms existing in/on benthic substrate and benthic detritus rather than pelagic organisms. This speculation may be supported by a finding by Svetashev et al. [46] that ArA content is remarkably higher in tropical holothurians than in the temperate species [46]. Scarce data are available on fatty acid composition of benthic prokaryotes and eukaryotes, bacteria, fungi and protozoa towards the beginning of ArA source in tropical marine food chain. The present result, high ArA levels in coral reef fish, suggests that the existence of an ArA-rich food chain may be widespread in coral reef areas, and that the widespread existence of ArA-rich food chain may lead to comparatively higher ArA contents in the coral reef fish. However, the issue of ArA origin in the coral-reef food web is still unclear.

Effort is needed to establish formulated diets appropriate for broodstock of coral reef fish. Feeding locally available trash fish rich in ArA would be at least one of the measures for improving broodstock performance in coral reef fish, until appropriate formulated diets are established for coral reef broodstock. Nevertheless, the information in the present study can be used as a guideline (a dietary ratio of DHA/ ArA of about 2 or greater) for development of appropriate broodstock and larval diets, to ensure high egg and larval quality of sustainable hatchery production in tropical and subtropical areas. We have already initiated a follow-up study on the effects of dietary ArA on reproductive performance and larval/fry quality in coral reef fish. Results of feeding trials will be published in separate papers.

\section{Acknowledgements}

We would like to thank Dr. K.D. Shearer, Northwest Fisheries Science Center NMFS, Seattle, WA USA, for his critical reading of the manuscript. The authors are also grateful to Mr. D.R. Chavez, INVEAsia Services Ltd, Thailand, Mr. E.S. Garibay, the Aquaculture Department, SEAFDEC, Philippines and Dr. H. Furuita, National Research Institute of Aquaculture, FRA, Japan for their technical assistants for conducting the present study. This study was supported by the collaborative project titled "Studies on Sustainable Production Systems of Aquatic Animals in Brackish Mangrove Areas" between Japan International Research Center for Agricultural Sciences, Japan and the Aquaculture Department, SEAFDEC, Philippines.

\section{References}

1. Johnston B (2007) Economics and marked analysis of the live reef-fish trade in the Asia-Pacific region. ACIAR Working Paper No.63, Australian Centre for International Agricultural Research, Canbera.

2. Marte CL (2003) Larviculture of marine species in Southeast Asia: current research and industry prospects. Aquaculture 227: 293-304

3. Tupper M, Sheriff N (2008) Capture-based aquaculture of groupers. In: A. Lovatelli, P.F. Holthus (eds), Capture-based aquaculture: Global overview, FAO Fisheries Technical Paper 508, Food and Agriculture Organization of the United Nations, Rome, pp. 217-253.

4. Watanabe T, Arakawa T, Kitajima C, Fujita S (1984) Effect of nutritional quality of broodstock diets on reproduction of red sea bream. Nippon Suian Gakkaishi 50: 495-501.

5. Izquierdo MS, Fernández-Palacios H, Tacon AGJ (2001) Effect of broodstock nutrition on reproductive performance of fish. Aquaculture 197: 25-42.

6. Sargent JR (1995) Origin and functions of eggs lipids: nutritional implications. In: N.R. Bromage, R.J. Roberts (eds), Broodstock Management and Egg and Larval Quality, Blackwell Science, London, pp. 353-372.
7. Castell JD, Bell JG, Tocher DR, Sargent JR (1994) Effects of purified diets containing different combinations of arachidonic and docosahexaenoic acid on survival, growth and fatty acid composition of juvenile turbot (Scophthalmus maximus). Aquaculture 128: 315- 333.

8. Bell JG, Sargent JR (2003) Arachidonic acid in aquaculture feeds: current status and future opportunities. Aquaculture 218:491-499.

9. Gibson RA (1983) Australian fish - an excellent source of both arachidonic acid and $\omega 3$ polyunsaturated fatty acids. Lipids 18: 743-752.

10. Gibson RA, Kneebone R, Kneebone GM (1984) Comparative levels of arachidonic acid and eicosapentaenoic acid in Malaysian fish. Comp Biochem Physiol C 78: 325-328.

11. Fogerty AC, Evans AJ, Ford GL, Kennett BH (1986) Distribution of $\omega 6$ and $\omega 3$ fatty acids in lipid classes in Australian fish. Nutrition Reports International 33: 777-786.

12. Rawdah TN, El-Faer MZ (1994) Fatty acid composition of three commercially important fish of the Arabian Gulf. Food Chem 51:193-196.

13. Ogata HY, Emata AC, Garibay ES, Furuita H (2004) Fatty acid composition of five candidate aquaculture species in Central Philippines. Aquaculture 236: 361-375.

14. Folch J, Lees M, Sloane-Stanley GH (1957) A simple method for the isolation and purification of total lipids from animal tissues. J Biol Chem 226: 497-509.

15. Juaneda P, Rocquelin G (1985) Rapid and covenient separation of phospholipids and non phosphorous lipids from rat heart using silica cartridges. Lipids 20: 40-41.

16. Miyashita K, Inukai N, Ota T, Sasaki S, Ota T (1999) Antioxidant activity of water extracts from fish eggs on PC liposomes. Nippon Suisan Gakkaishi 65 488-494.

17. Irving DO, Watson K (1976) Mitochodrial enzymes of tropical fish: A comparison with fish from cold-waters. Comp Biochem Physiol B 54: 81-92.

18. Alava VR, Priolo FMP, Arnaiz M, Toledo JD (2004) Amino and fatty acid profiles of wild-sourced grouper (Epinephelus coioides) broodstock and larvae. In: M.A. Rimmer, S. McBride, K.C. Williamas (eds), Advances in Grouper Aquaculture, ACIAR Monograph 110, Canbera, pp. 53-54.

19. Tamaru CS, Ako H, Lee C-S (1992) Fatty acid and amino acid profiles of spawned eggs of striped mullet, Mugil cephalus L. Aquaculture 105: 83-94.

20. Ako H, Tamaru CS, Lee C-S (1994) Chemical and physical differences in milkfish (Chanos chanos) eggs from natural and hormonally induced spawns. Aquaculture 127: 157-167.

21. Nocillado JN, Peñaflorida VD, Borlongan, IG (2000) Measures of egg quality in induced spawns of the Asian sea bass, Lates calcarifer Bloch. Fish Physiol Biochem 22; 1-9.

22. Cejas JR, Almansa E, Villamandos JE, Badía P, Bolaños A, et al. (2003) Lipid and fatty acid composition of ovaries from wild fish and ovaries and eggs from captive fish of white sea bream (Diplodus sargus). Aquaculture 216: 299-313.

23. Faulk C, Holt GJ (2005) Advances inrearing cobia Rachycentron canadum larvae in recirculating aquaculture systems: Live prey enrichment and greenwater culture. Aquaculture 249: 231-243.

24. Tocher DR, Sargent JR (1984) Analyses of lipids and fatty acids in ripe roes of some Northwest European Marine Fish. Lipids 19: 492-499.

25. Takama K, Suzuki T, Yoshida K, Arai H, Anma H (1994) Lipid content and fatty acid composition of phospholipids in white-flesh species. Fisheries Science 60 177-184.

26. Anderson AJ, Arthington AH, Anderson S (1990) Lipid classes and fatty acid composition of the eggs of some Australian fish. Comp Biochem Physiol B 96 267-270.

27. Bell MV, Dick JR, Thrush M, Navarro JC (1996) Decreased 20:4n-6/20:5n-3 ratio in sperm from cultured sea bass, Dicentrarchus labrax, broodstock compard with wild fish. Aquaculture 144: 189-199.

28. Asturiano JF, Sorbera LA, Carrillo M, Zanuy S, Ramos J,et al,(2001) 
Citation: Suloma A, Ogata HY (2011) Arachidonic acid is a Major Component in Gonadal Fatty acids of Tropical Coral Reef fish in the Philippines and Japan. J Aquac Res Development 2:111. doi:10.4172/2155-9546.1000111

Reproductive performance in male European sea bass (Dicentrarchus labrax, L.) fed two PUFA-enriched experimental diets: a comparison with males fed a wet diet. Aquaculture 194: 173-190.

29. Ota T, Takagi T (1989) Fatty acids of lipids from fish testes with particular reference to furan fatty acids. Bulletin of the Faculty of Fisheries Hokkaido University 40: 193-201.

30. Hiratsuka T, Kitagawa T, Matsue Y, Hashidume M, Wada S (2004) Lipid class and fatty acid composition of phospholipids from the gonads of skipjack tuna . Fisheries Science 70: 903-909.

31. Sorensen PW, Goetz FW (1993) Pheromonal and reproductive function of F-prostaglandins and their metabolites in teleost fish. J Lipid Mediat 6: 385-393.

32. Ogata H, Kitamutra S, Takashima F (1994) Release of 13, 14-dihydro-ketoprostaglandin $F 2 \alpha$, a sex pheromone, to water by cobitid loach following ovulatory stimulation. Fisheries Science 60: 143-148.

33. Stacey NE, Goetz FW (1982) Role of prostaglandins in fish reproduction. Canadian Journal of Fisheries and Aquatic Sciences 39: 92-98.

34. van der Kraak G, Chang JP (1990) Arachidonic acid stimulates steroidgenesis in goldfish preovulatory ovarian follicles. Gen Comp Endocrinol 77: 221-228.

35. Wade MG, van der Kraak G (1993) Arachidonic acid and prostaglandin E2 stimulate testosterone production by goldfish testis in vitro. Gen Comp Endocrinol 90: 109-118.

36. Asturiano JF, Sorbera LA, Zanuy S, Carriolla M (2000) Effects of polyunsaturated fatty acids and gonadtropin on prostaglandin series $E$ production in a primary testis cell culture system for the European sea bass. J Fish Biol 57: 1563-1574.

37. Koven W, van Anholt R, Lutzky S, Atia IB, Nixon O, et al. (2003) The effect of dietary arachidonic acid on growth, survival, and cortisol levels in different-age gilthead seabream larvae (Sparus auratus) exposed to handling or daily salinity change. Aquaculture 228: 307-320.

38. Sargent JR, Whittle KJ (1981) Lipids and hydrocarbons in the marine food web. In: A.R. Longhurst (eds), Analysis of Marine Ecosystems, Academic Press, London, pp. 491-533.

39. Renaud SM, Thinh L-V, Parry DL (1999) The gross chemical composition and fatty acid composition of 18 species of tropical Australian microalgae for possible use in mariculture. Aquaculture 170: 147-159.

40. Shamsudin L (1998) Seasonal variation of fatty acid content in natural microplankton from the Tumpat coastal waters of the South China Sea. Arch Physiol Biochem 106: 253-260.

41. McKinnon AD, Duggan S, Nichols PD, Rimmer MA, Semmens G, et al. (2003) The potential of tropical paracalanid copepods as live feeds in aquaculture. Aquaculture 223: 86-106.

42. Johns RB, Nicholas PD, Perry GJ (1979) Fatty acid composition of ten marine algae from Australian waters. Phytochemistry 18: 799-802.

43. Dembitsky VM, Pechenkina-Shubina EE, Rozentsvet OA (1991) Glycolipids and fatty acids of some seaweeds and marine grasses from the Black Sea. Phytochemistry 30: 2279-2283.

44. Vaskovsky VE, Khotimchenko SV, Xia B, Hefang L (1996) Polar lipids and fatty acids of some marine macrophytes from the Yellow Sea. Phytochemistry 42 1347-1356.

45. Dunstan GA, Sinclair AJ, O'Dea K, Naughton JM (1988) The lipid content and fatty acid composition of various marine species from Southern Australian coastal waters. Comp Biochem Physiol B 91: 165-169.

46. Svetashev VI, Levin VS, Lam CN, Nga DT (1991) Lipid and fatty acid composition of holothurians from tropical and temperate waters. Comp Biochem Physiol B 98: 489-494. 